\title{
Dietary Selenium Influences Calcium Release and Activation of MLCK in Uterine Smooth Muscle of Rats
}

\author{
Mengyao Guo $\cdot$ Tingting Lv $\cdot$ Fangning Liu • \\ Haiyang Yan • Teng Wei • Hua Cai • Wulin Tian • \\ Naisheng Zhang $\cdot$ Zhe Wang $\cdot$ Guanghong Xie
}

Received: 3 May 2013 / Accepted: 16 May 2013 /Published online: 1 June 2013

(C) The Author(s) 2013. This article is published with open access at Springerlink.com

\begin{abstract}
We sought to elucidate the effects of different concentrations of dietary selenium on calcium ion release, MLCK levels, and muscle contraction in the uterine smooth muscle of rats. The selenium (Se) content of blood and of uterine smooth muscle tissues was detected by fluorescence spectrophotometry. $\mathrm{Ca}^{2+}$ content was measured by atomic absorption spectroscopy. Calmodulin (CaM) and MLCK RNA and protein levels were analyzed by quantitative real-time polymerase chain reaction and Western blot, respectively. Dietary Se intake increased the Se levels in the blood and in uterine smooth muscle tissues and increased the $\mathrm{Ca}^{2+}$ concentration in uterine smooth muscle tissues. The addition of Se also promoted $\mathrm{CaM}$ expression and enhanced MLCK activation in uterine smooth muscle tissues. In conclusion, $\mathrm{Ca}^{2+}, \mathrm{CaM}$, and MLCK were regulated by Se in uterine smooth muscle; Se plays a major role in regulating smooth muscle contraction in the uterus.
\end{abstract}

Keywords Selenium $\cdot \mathrm{Ca}^{2+} \cdot \mathrm{CaM} \cdot \mathrm{MLCK}$.

Uterine smooth muscle

Mengyao Guo, Tingting Lv, Fangning Liu, and Haiyang Yan contributed equally to this work.

M. Guo $\cdot$ T. Lv $\cdot$ F. Liu $\cdot$ T. Wei $\cdot$ W. Tian $\cdot$ N. Zhang $\cdot$ Z. Wang $\cdot$

G. Xie $(\bowtie)$

College of Veterinary Medicine, Jilin University,

Changchun, Jilin Province 130062, China

e-mail: xiegh@jlu.edu.cn

H. Yan

College of Quartermaster Technology, Jilin University,

Changchun 130062, China

H. Cai

Jilin Teachers' Institute of Engineering \& Technology,

Changchun 130052, China

\section{Introduction}

The element selenium (Se) is recognized as an essential nutrient [1]. In 1973, the biochemical and biological roles of Se were further revealed when it was established as an essential component of the active site of the selenoenzyme GPx $[2,3]$. Se, which is closely associated with health and disease, is a nutritionally essential trace element [4]. It has been reported that Se plays an important role in chemoprevention [5, 6], neurobiology [7], aging [8], immune function $[9,10]$, muscle metabolism [11], reproduction [12], redox reactions [9], and many other aspects of health $[13,14]$.

Previous research has indicated that the activity of $\mathrm{Ca}^{2+}$ release channels was modulated by Se in the sarcoplasm [15]. In addition, during PC12 cell differentiation, Se could reinforce the elevation of cytosolic $\mathrm{Ca}^{2+}$ concentration and stimulate the release of catecholamines [16]. $\mathrm{Ca}^{2+}$ can function as an intracellular information carrier, binding to calmodulin $(\mathrm{CaM})$ for signal translation [17]. Smooth muscle MLCK plays a regulatory role in the contraction of smooth muscle by phosphorylating $20 \mathrm{kDa}$ myosin light chain (MLC20) in a $\mathrm{Ca}^{2+} / \mathrm{CaM}$-dependent manner.

Many muscle diseases are associated with $\mathrm{Se}$, but the relationship between $\mathrm{Se}, \mathrm{Ca}^{2+} / \mathrm{CaM}$, and MLCK has not been reported. We therefore examined the concentration of $\mathrm{Ca}^{2+}$, the expression of CaM, and the activity of MCLK in the uterine smooth muscle tissue of rats fed with different quantities of Se and probed the effects of $\mathrm{Se}$ on $\mathrm{Ca}^{2+} / \mathrm{CaM}$ and MLCK. The function of Se in uterine contraction was also explored.

\section{Materials and Methods}

Animals

In total, 90 adult female Wistar rats (6-8 weeks old, weighing $160-175 \mathrm{~g}$ ) were used and were provided by the Center of 
Experimental Animals of Baiqiuen Medical College, Jilin University, China. The experimental procedures were conducted according to the US NIH Guide for the Care and Use of Laboratory Animals and were approved by the Institutional Animal Care and Use Committee of Jilin University.

\section{Experimental Groups and Administration}

The rats were randomly divided into three groups (30 rats per group) as follows:

1. Low level group (LG) rats were fed a Se-deficient granulated diet (containing $0.02 \mathrm{mg} / \mathrm{kg} \mathrm{Se}$, to simulate the Se deficiency that exists in Jilin Province, China).

2. Normal level group (NG) rats were fed a $0.3-\mathrm{mg} / \mathrm{kg}$ Se-supplemented granulated diet.

3. High level group (HG) rats were fed a $1.0-\mathrm{mg} / \mathrm{kg}$ Se-supplemented granulated diet.

Each group was separated into three mini-groups (ten rats each) that were fed for 20,40 , or 60 days. The animals were maintained under standard husbandry conditions of light $(12 \mathrm{~h})$ and dark $(12 \mathrm{~h})$ at a temperature of $25 \pm 1{ }^{\circ} \mathrm{C}$ with food and drinking water ad libitum. After euthanasia with sodium pentobarbital, the plasma and uterine smooth muscle tissues were quickly collected. The tissues were rinsed with ice-cold sterile deionized water, frozen immediately in liquid nitrogen, and stored at $-80{ }^{\circ} \mathrm{C}$.

Detection of the Se Contents of Blood and Uterine Smooth Muscle Tissues

The Se contents of blood and uterine smooth muscle were estimated using the method described by Hasunuma et al. [18]. This assay is based on the principle that the Se within samples is converted to selenous acid by acid digestion. The reaction between selenous acid and aromatic o-diamines, such as 2,3-diamino-naphthalene, leads to the formation of 4,5-benzopiazselenol, which displays a brilliant lime-green fluorescence when excited at $366 \mathrm{~nm}$ in cyclohexane. The fluorescence of extracted cyclohexane was measured with a fluorescence spectrophotometer with an excitation wavelength of $366 \mathrm{~nm}$ and an emission wavelength of $520 \mathrm{~nm}$. The Se content in the samples was calculated based on a standard curve.

Assay for $\mathrm{Ca}^{2+}$ Content

Different volumes of a $\mathrm{Ca}^{2+}$ standard stock solution were placed in $50 \mathrm{~mL}$ measuring flasks and diluted with water to prepare $0.5,1.0,2.0,5.0$, and $10.0 \mathrm{mg} / \mathrm{L}$ standards. Specimens were placed into an oven at $72{ }^{\circ} \mathrm{C}$ for 3 days, and $18 \mathrm{mg}$ of this dried material was then accurately weighed and added to a $50-\mathrm{mL}$ beaker. Three milliliters of $\mathrm{HNO}_{3}$ and $2 \mathrm{~mL}$ of $\mathrm{HClO}_{4}$ were added. After being left overnight covered by a watch glass, the specimens were decomposed at a low temperature and heated until almost dry. The contents of specimens were then soaked, transferred, and fixed by $10 \mathrm{~mL}$ deionized water and analyzed by atomic absorption spectroscopy. The $\mathrm{Ca}^{2+}$ content in the samples was calculated from a standard curve.

\section{Quantitative Real-Time Polymerase Chain Reaction}

Total RNA was isolated from the uterine smooth muscle samples (50 mg tissue) using the TRIzol reagent according to the manufacturer's instructions (Invitrogen, China). The concentration and purity of the total RNA were determined spectrophotometrically at 260/280 nm. First-strand cDNA was synthesized from $5 \mu \mathrm{g}$ of total RNA using oligo (dT) primers and Superscript II reverse transcriptase according to the manufacturer's instructions (Invitrogen, USA). The synthesized cDNA was diluted 1:4 with sterile water and stored at $-80{ }^{\circ} \mathrm{C}$.

Primer Premier software (PREMIER Biosoft International, USA) was used to design specific primers for CaM, MLCK, and $\beta$-actin based on known sequences (Table 1). Quantitative real-time PCR was performed on an ABI PRISM 7500 Detection System (Applied Biosystems, USA). Reactions were performed in a $25-\mu \mathrm{L}$ reaction mixture containing $12 \mu \mathrm{L}$ of $2 \times$ SYBR Green I PCR Master Mix (TaKaRa, China), $2 \mu \mathrm{L}$ of diluted cDNA, $0.5 \mu \mathrm{L}$ of each primer $(10 \mu \mathrm{M}), 0.8 \mu \mathrm{L}$ of $50 \times$ ROX reference Dye II, and $9.2 \mu \mathrm{L}$ of PCR-grade water. The PCR protocol for CaM, MLCK, and $\beta$-actin consisted of $95{ }^{\circ} \mathrm{C}$ for $30 \mathrm{~s}$ followed by 40 cycles of $95{ }^{\circ} \mathrm{C}$ for $15 \mathrm{~s}, 60^{\circ} \mathrm{C}$ for $30 \mathrm{~s}$, and $60^{\circ} \mathrm{C}$ for $30 \mathrm{~s}$. A melting curve analysis showed only one peak for each PCR product. The amplification efficiency for each gene was determined using the DART-PCR program [19]. The mRNA relative abundance was calculated according to the method of Pfaffl [20], accounting for gene-specific efficiencies, and was normalized to the mean expression of $\beta$-actin. The results (fold changes) were expressed as $2^{-\Delta \Delta \mathrm{Ct}}$, in which $\Delta \Delta \mathrm{Ct}=$ $\left(\mathrm{Ct}_{\mathrm{CaM} / \mathrm{MLCK}}-\mathrm{Ct}_{\beta \text {-actin }}\right) t-\left(\mathrm{Ct}_{\mathrm{CaM} / \mathrm{MLCK}}-\mathrm{Ct}_{\beta \text {-actin }}\right) c$, where $\mathrm{Ct}_{\mathrm{CaM} / \mathrm{MLCK}}$ and $\mathrm{Ct}_{\beta \text {-actin }}$ are the cycle thresholds for $\mathrm{CaM}$, MLCK, and $\beta$-actin genes, respectively, $t$ is the treatment group, and $c$ is the control group.

\section{Western Blot Analysis}

Uterine smooth muscle tissues were homogenized, and total protein was extracted according to the manufacturer's protocols; protein concentrations were determined using the BCA protein assay kit. Samples with equal amounts of protein $(50 \mu \mathrm{g})$ were separated on $10 \%$ SDS polyacrylamide gels, transferred to a polyvinylidene difluoride 
Table 1 Primers used for quantitative real-time PCR

\begin{tabular}{|c|c|c|c|c|}
\hline Target gene (dairy cow) & GenBank accession no. & Primer & Sequence $\left(5^{\prime}-3^{\prime}\right)$ & PCR fragment length (bp) \\
\hline $\mathrm{CaM}$ & NM 031969.2 & $\begin{array}{l}\text { Forward } \\
\text { Reverse }\end{array}$ & $\begin{array}{l}\text { 5'-AATGTTTACTAAGGGAGCA-3' } \\
\text { 5'-ACAACTTGGAATGGACGT-3' }\end{array}$ & 151 \\
\hline MLCK & NM 001105874.2 & $\begin{array}{l}\text { Forward } \\
\text { Reverse }\end{array}$ & $\begin{array}{l}\text { 5'-TGCTTCTGACATACGGAGTT-3' } \\
\text { 5'-GACATTGAAAGAGGTGCTG-3' }\end{array}$ & 157 \\
\hline$\beta$-actin & NM 031144.3 & $\begin{array}{l}\text { Forward } \\
\text { Reverse }\end{array}$ & $\begin{array}{l}\text { 5'-TAAAACGCAGCTCAGTAACAGTCG-3' } \\
\text { 5'-TGCAATCCTGTGGCATCCATGAAA-3' }\end{array}$ & 182 \\
\hline
\end{tabular}

membrane, and blocked in $5 \%$ skim milk in TTBS for $2 \mathrm{~h}$ at room temperature. The membranes were then incubated overnight at $4{ }^{\circ} \mathrm{C}$ with primary antibodies (1:1,000 dilution). After washing the membrane with TTBS, incubation with a 1:5,000 dilution $(v / v)$ of secondary antibody was conducted for $1 \mathrm{~h}$ at room temperature. Protein expression was detected with an enhanced chemiluminescence detection system, and the membrane was exposed to an X-ray film. The $\beta$-actin signal was used as a loading control.

\section{MLCK Activity Assays}

The $\mathrm{Ca}^{2+} / \mathrm{CaM}$-dependent activity of MLCK was measured by the rate of $\left[\gamma_{-}{ }^{32} \mathrm{P}\right] \mathrm{ATP}$ incorporation into myosin light chain substrate according to the method of Ren et al. [21]. MLCK activity was assayed in a $50-\mu 1$ reaction containing $3.25 \mathrm{~g} / \mathrm{L}$ substrate, $5 \mathrm{mmol} / \mathrm{L}$ DTT, $0.1 \mathrm{mmol} / \mathrm{L} \mathrm{CaCl}_{2}$, $0.5 \mathrm{mmol} / \mathrm{L} \mathrm{KCl}, 0.1 \mathrm{mmol} / \mathrm{L}$ BSA, $50 \mathrm{mmol} / \mathrm{L}$ HEPES $(\mathrm{pH}=7.0)$, and $0.2 \mathrm{mmol} / \mathrm{L}[\gamma-32 \mathrm{P}] \mathrm{ATP}$. MLCK was diluted into this reaction, which was then incubated at room temperature for $30 \mathrm{~min}$. Forty microliters from this reaction was spotted on Whatman chromatography paper, followed by three washes with $75 \mathrm{mmol} / \mathrm{L}$ phosphoric acid, a 5-min $95 \%$ ethanol wash, and air-drying. Scintillation counting was performed to measure incorporated ${ }^{32} \mathrm{P}$.

\section{Data Analysis}

Statistical analyses were performed using the SPSS software (ver. 13 for Windows; SPSS Inc., Chicago, IL, USA). Significance was determined by a one-way ANOVA using a significance level of $P<0.05$. The data were assessed using the Tukey-Kramer method for multiple comparisons. All values are expressed as the means $\pm \mathrm{SD}$.

\section{Results}

Se Levels in Blood and Uterine Tissues

The effects of dietary Se on the Se levels in blood and uterine smooth muscle are shown in Fig. 1. Compared with the NG, the Se levels in blood and uterine smooth muscle tissues were increased significantly in the HG and reduced significantly in the LG at each sampling time. In line with the duration of treatment, the Se levels in blood and uterine smooth muscle tissues steadily increased in the HG and the NG. Compared with the Se level in blood, the uterine smooth muscle Se level behaved slightly differently. The Se concentration in both blood and uterine smooth muscle tissues reached a plateau after 40 days in the NG. In the HG, the Se concentration in blood also reached a plateau after 40 days, but the level of Se in uterine smooth muscle tissues continued to increase. The Se concentrations in blood and uterine smooth muscle tissues significantly decreased in the LG over time, but this dissipation was slower in blood.

\section{The Concentration of $\mathrm{Ca}^{2+}$ in Uterine Tissues}

The $\mathrm{Ca}^{2+}$ concentration of uterine smooth muscle tissues was detected by atomic absorption spectroscopy. There was an obvious linear correlation between $\mathrm{Se}$ and $\mathrm{Ca}^{2+}$ concentration. This result is shown in Fig. 2. With increasing doses of dietary Se, the effect was obvious. Compared with the $\mathrm{NG}$, the $\mathrm{Ca}^{2+}$ concentration of uterine smooth muscle tissues was increased significantly in the $\mathrm{HG}$ and reduced significantly in the LG at 20,40 , or 60 days. The uterine smooth muscle $\mathrm{Ca}^{2+}$ concentration reached a plateau after 40 days in the $\mathrm{NG}$, while in the $\mathrm{HG}$, the $\mathrm{Ca}^{2+}$ concentration continued to rise until the end of the experiment. There was a sustained decrease of Se levels in the LG.

\section{Effect of Se on the Expression of $\mathrm{CaM}$}

$\mathrm{CaM}$ has a key role as a $\mathrm{Ca}^{2+}$ signal-regulatory protein. The mRNA and protein expression levels of $\mathrm{CaM}$ were measured by quantitative RT-PCR and Western blot analysis in the present study. Compared with the NG, there was a significant reduction $(P<0.05)$ in CaM mRNA in the LG. The CaM mRNA level was increased in the HG, but the difference from the NG was not statistically significant $(P>0.1)$. During the experiment, the CaM mRNA level continued to decrease in the LG, slightly increased in the HG, and did not change in the NG. The results are shown in Fig. 3b. 
Fig. 1 Se contents of blood and uterus tissues. Three concentrations of Se with three sampling points in mouse fed diets. a Se content of blood. b Se content of uterus tissues. Data are presented as the means \pm SEM $(n=10) . L G=$ low level group, $N G=$ normal level group, $H G=$ high level group

$* P<0.01$, significantly different from the NG. ${ }^{\#} P<0.01$, significantly different from the 20-day sampling point in the same group a

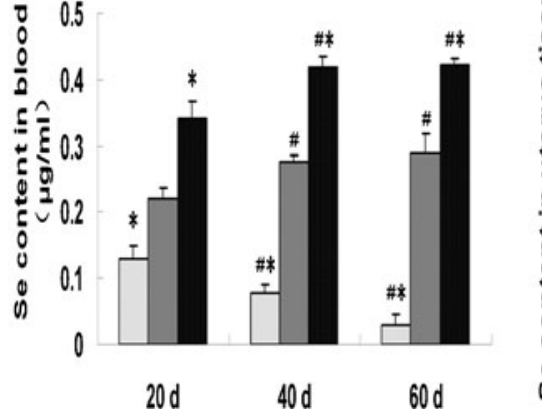

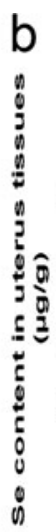

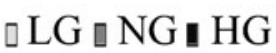

0.8

.

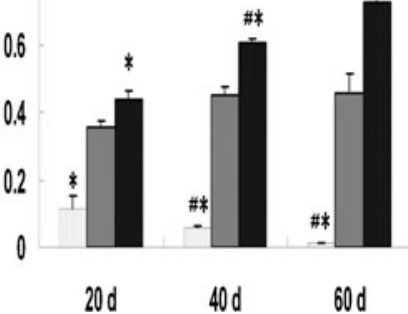

The protein level of CaM was significantly increased in the $\mathrm{HG}$ and significantly decreased in the LG compared to the NG (Fig. 3a). Over the course of the experiment, the expression of $\mathrm{CaM}$ protein continually increased in the $\mathrm{HG}$ and continually decreased in the LG.

The Influence on the Expression and Activity of MLCK

MLCK is a key signaling molecule for smooth muscle contraction. MLCK mRNA was measured by quantitative RT-PCR (Fig. 4b); compared with the NG, there was a significant reduction $(P<0.05)$ in MLCK mRNA in the LG. MLCK mRNA was increased in the HG, but it was not significantly different $(P>0.1)$ from the NG. During the course of the experiment, the MLCK mRNA level continued to decrease in the LG, slightly increased in the HG, and did not change in the NG.

MLCK protein was measured by Western blot (Fig. 4a). Compared with the $\mathrm{NG}$, the expression of $\mathrm{CaM}$ protein was increased significantly in the HG and suppressed in the LG. The level of MLCK protein continued to increase until the end of experiment in the HG and continued to decrease in the LG. The activity of the MLCK protein was also assayed (Fig. 4c). Compared with the NG, MLCK had a higher catalytic activity in the HG $(P<0.01)$, but the catalytic activity was significantly reduced in the LG $(P<0.01)$.

\section{Discussion}

Selenium is an essential nutrient for humans and animals [22]. Many diseases are caused by Se deficiency [23]. Many forms of cardiac and skeletal muscle disorders that are defined as nutritional muscular dystrophy are caused by Se deficiency $[24,25]$. However, data on the relationship between Se and smooth muscle function, especially for the uterine smooth muscle, are lacking.

The Se concentrations in blood and uterine smooth muscle are most commonly used as the biomarkers of Se status in various parts of the body [26]. In the present study, the Se concentrations in blood and uterine smooth muscle tissues were significantly increased in the $\mathrm{HG}$ and significantly reduced in the LG at 20,40, and 60 days $(P<0.05)$, and the magnitude of these changes steadily increased over the course of the experiment. It is significant that the Se concentrations in the blood and uterine smooth muscle tissues were affected by the Se intake. This result was in agreement with previous studies on other tissues, including smooth muscle tissues [27]. The Se level in blood reached a plateau after 40 days in the HG. In the LG, the rate of Se dissipation in blood was lower than in uterine smooth muscle. Thus, we inferred that the blood serves as a Se reservoir and has a buffering action on the dietary intake of Se before it can reach systemic tissues. The dose of dietary selenium intake significantly influenced the Se concentration in uterine tissues.

$\mathrm{Ca}^{2+}$ ions were detected by atomic absorption spectroscopy. The increased $\mathrm{Ca}^{2+}$ concentration correlated with the increased content of dietary Se. Over the course of the experiment, the $\mathrm{Ca}^{2+}$ concentration of uterine smooth muscle tissues continued to increase in the HG and continued to

\section{$\square \mathrm{LG} \square \mathrm{NG}$ घG}

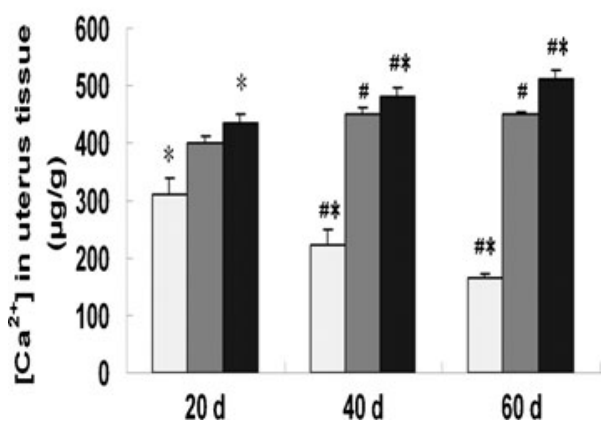

Fig. 2 The $\left[\mathrm{Ca}^{2+}\right]$ of uterus tissues. $\left[\mathrm{Ca}^{2+}\right]$ were detected by atomic absorption spectrophotometer, and specimens were discomposed under low temperature and steamed until almost being dry. Data were derived from the uterus homogenate supernatant and are presented as the means \pm SEM $(n=10) . L G=$ low level group, $\mathrm{NG}=$ normal level group, $\mathrm{HG}=$ high level group. ${ }^{*} \mathrm{P}<0.01$, significantly different from the $\mathrm{NG}$. ${ }^{\#} P<0.01$, significantly different from the 20 -day sampling point in the same group 
Fig. 3 The expression of CaM in uterus tissues. a Western blotting was performed to detect $\mathrm{CaM}$ protein levels in the low level group $(L G)$, normal level group $(N G)$, and high level group $(H G)$. b qPCR was performed to detect the mRNAs of $\mathrm{CaM} ; \beta$-actin was used as a control. Values are presented as the means \pm SEM $(n=10)$.

$* P<0.01$, significantly different from the NG. ${ }^{\#} P<0.01$, significantly different from the 20 -day sampling point in the same group
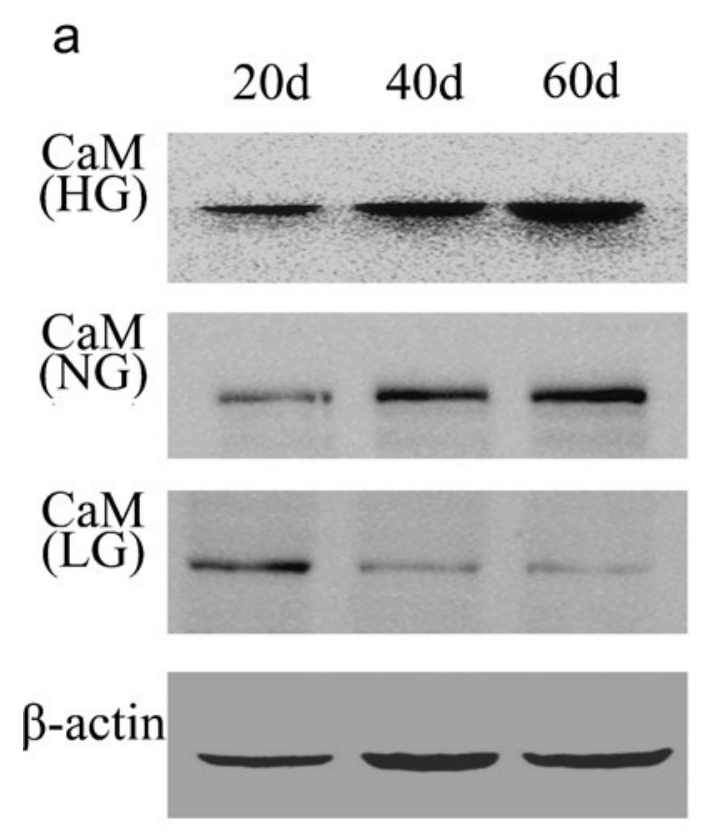
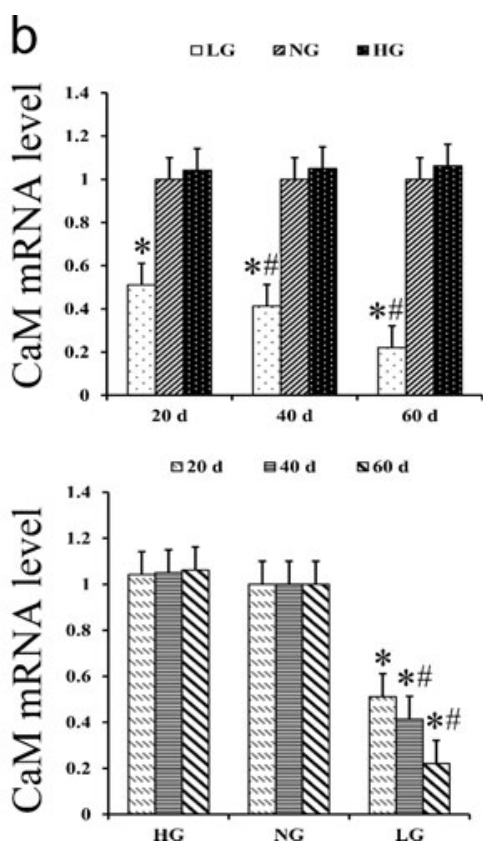

decrease in the LG. This result is in agreement with a previous study of the effects of Se on the intracellular calcium concentration [28]. It was suggested that Se was involved in calcium channel mobilization [29]. CaM has a key role as a $\mathrm{Ca}^{2+}$ signal-regulatory protein [30]. In the present study, CaM mRNA did not increase significantly
Fig. 4 Effect of Se on the expression and activity of MLCK. a Western blotting was performed to detect MLCK protein levels in the low level group $(L G)$, normal level group $(N G)$, and high level group $(H G)$. b qPCR was performed to detect the mRNAs of MLCK; $\beta$-actin was used as a control. c The activity level of isolated MLCK in uterus smooth muscle tissues. Values are presented as the means \pm SEM $(n=10)$. $* P<0.01$, significantly different from the NG. ${ }^{*} P<0.01$, significantly different from the 20-day sampling point in the same group

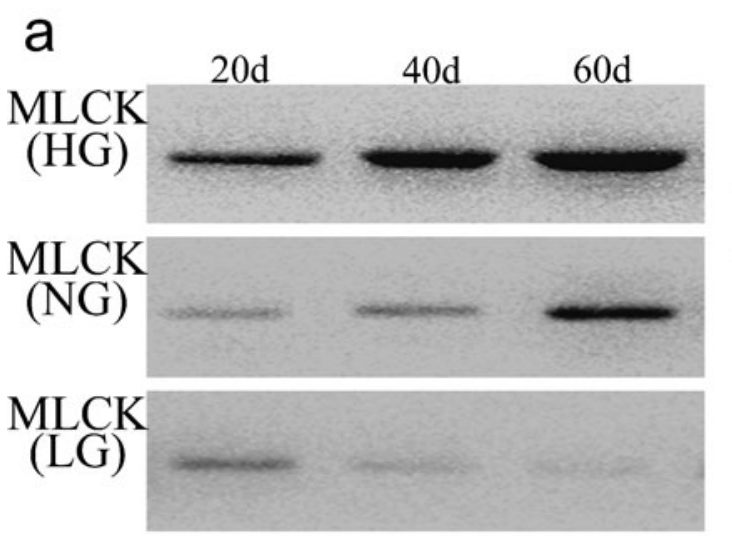

b
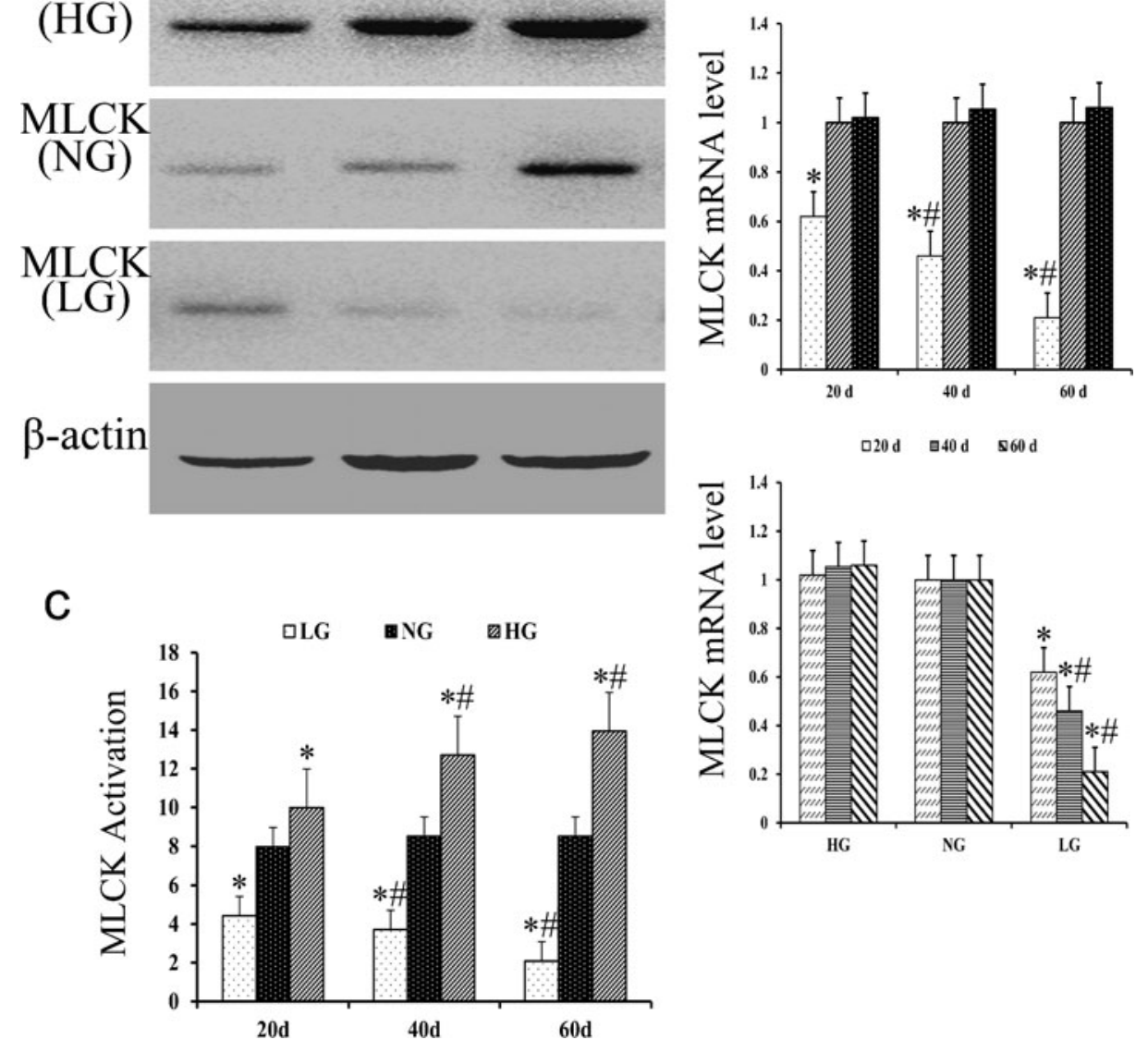
with enhanced Se intake, but $\mathrm{CaM}$ protein expression did increase. Over the course of the experiment, the expression of $\mathrm{CaM}$ mRNA and protein continued to increase. These results indicated that $\mathrm{CaM}$ protein expression was influenced by Se intake, and the increased $\mathrm{Ca}^{2+}$ concentration was the direct result of the increased levels of $\mathrm{CaM}$. Se initially played an indirect role in increasing the $\mathrm{Ca}^{2+}$ concentration.

Smooth muscle contraction, unlike skeletal and cardiac muscle contraction, is a slow process. Enormous variability exists between different smooth muscle cells, making it difficult to draw general conclusions concerning their signaling mechanisms [31]. MLCK is a key protein in the smooth muscle contraction process $[32,33]$. Contraction is achieved through the phosphorylation of the $\mathrm{P}$ chain of myosin by MLCK and can be activated by $\mathrm{Ca}^{2+} / \mathrm{CaM}$ [34]. In the present study, the expression of MLCK mRNA and protein in uterine smooth muscle tissues increased significantly with increased Se intake. The activity of MLCK was also significantly increased. Our results showed that the expression of MLCK was promoted by increasing the Se concentration in uterine smooth muscle tissues, and the activity of MLCK was promoted by increasing $\mathrm{Ca}^{2+} / \mathrm{CaM}$ levels, which were induced by increased dietary Se. Because there is no troponin in smooth muscle, the smooth muscle contraction process is achieved through the phosphorylation of the P chain of myosin by MLCK [35]. In the present study, the expression and activity of MLCK were promoted by increasing the Se content in uterine smooth muscle tissues. This result indicates that Se could promote uterine smooth muscle contraction.

In conclusion, with the increase of dietary Se, the Se concentrations in blood and uterine smooth muscle tissues were obviously increased. Meanwhile, the $\mathrm{Ca}^{2+}$ and $\mathrm{CaM}$ levels were also increased. These results confirmed that the $\mathrm{Ca}^{2+}$ and $\mathrm{CaM}$ levels were regulated by $\mathrm{Se}$ in uterine smooth muscle. We also found that Se promoted the expression and activity of MLCK in uterine smooth muscle tissues. Therefore, it was concluded that Se plays a major role in regulating the contraction process of the uterine smooth muscle.

Acknowledgment This work was supported by the National Natural Science Foundation of China (Nos. 31101865).

Open Access This article is distributed under the terms of the Creative Commons Attribution License which permits any use, distribution, and reproduction in any medium, provided the original author(s) and the source are credited.

\section{References}

1. Schomburg L, Schweizer U, Kohrle J (2004) Selenium and selenoproteins in mammals: extraordinary, essential, enigmatic.
Cell Mol Life Sci: CMLS 61(16):1988-1995. doi:10.1007/ s00018-004-4114-Z

2. Flohe L, Gunzler WA, Schock HH (1973) Glutathione peroxidase: a selenoenzyme. FEBS Lett 32(1):132-134

3. Rotruck JT, Pope AL, Ganther HE, Swanson AB, Hafeman DG, Hoekstra WG (1973) Selenium: biochemical role as a component of glutathione peroxidase. Science 179(4073):588-590

4. Rayman MP (2012) Selenium and human health. Lancet 379(9822):1256-1268. doi:10.1016/S0140-6736(11)61452-9

5. Combs GF Jr, Clark LC, Turnbull BW (2001) An analysis of cancer prevention by selenium. Biofactors 14(1-4):153-159

6. Li JL, Gao R, Li S, Wang JT, Tang ZX, Xu SW (2010) Testicular toxicity induced by dietary cadmium in cocks and ameliorative effect by selenium. Biometals 23(4):695-705. doi:10.1007/ s10534-010-9334-0

7. Schweizer U, Schomburg L, Savaskan NE (2004) The neurobiology of selenium: lessons from transgenic mice. J Nutr 134(4):707710

8. Martin-Romero FJ, Kryukov GV, Lobanov AV, Carlson BA, Lee BJ, Gladyshev VN, Hatfield DL (2001) Selenium metabolism in Drosophila: selenoproteins, selenoprotein mRNA expression, fertility, and mortality. J Biol Chem 276(32):29798-29804. doi:10.1074/jbc.M100422200

9. Rayman MP (2000) The importance of selenium to human health. Lancet 356(9225):233-241. doi:10.1016/S0140-6736(00)02490-9

10. Hoffmann PR, Berry MJ (2008) The influence of selenium on immune responses. Mol Nutr Food Res 52(11):1273-1280. doi:10.1002/mnfr.200700330

11. Chariot P, Bignani O (2003) Skeletal muscle disorders associated with selenium deficiency in humans. Muscle Nerve 27(6):662668. doi:10.1002/mus.10304

12. Kaur P, Bansal MP (2005) Effect of selenium-induced oxidative stress on the cell kinetics in testis and reproductive ability of male mice. Nutrition 21(3):351-357. doi:10.1016/j.nut.2004.05.028

13. Brown KM, Arthur JR (2001) Selenium, selenoproteins and human health: a review. Public Health Nutr 4(2B):593-599

14. Mahmoud KZ, Edens FW (2005) Influence of organic selenium on hsp70 response of heat-stressed and enteropathogenic Escherichia coli-challenged broiler chickens (Gallus gallus). Comp Biochem Physiol Toxicol Pharmacol : CBP 141(1):69-75. doi:10.1016/ j.cca.2005.05.005

15. Grumolato L, Ghzili H, Montero-Hadjadje M, Gasman S, Lesage J, Tanguy Y, Galas L, Ait-Ali D, Leprince J, Guerineau NC, Elkahloun AG, Fournier A, Vieau D, Vaudry H, Anouar Y (2008) Selenoprotein T is a PACAP-regulated gene involved in intracellular $\mathrm{Ca}^{2+}$ mobilization and neuroendocrine secretion. FASEB J 22(6):1756-1768. doi:10.1096/fj.06-075820

16. Marin-Prida J, Penton-Rol G, Rodrigues FP, Alberici LC, Stringhetta K, Leopoldino AM, Naal Z, Polizello AC, LlopizArzuaga A, Rosa MN, Liberato JL, Santos WF, Uyemura SA, Penton-Arias E, Curti C, Pardo-Andreu GL (2012) CPhycocyanin protects SH-SY5Y cells from oxidative injury, rat retina from transient ischemia and rat brain mitochondria from $\mathrm{Ca}(2+)$ /phosphate-induced impairment. Brain Res Bull 89(56):159-167. doi:10.1016/j.brainresbull.2012.08.011

17. Hidalgo CG, Chung CS, Saripalli C, Methawasin M, Hutchinson KR, Tsaprailis G, Labeit S, Mattiazzi A, Granzier HL (2013) The multifunctional $\mathrm{Ca}^{2+} /$ calmodulin-dependent protein kinase II delta (CaMKIIdelta) phosphorylates cardiac titin's spring elements. J Mol Cell Cardiol 54:90-97. doi:10.1016/j.yjmcc.2012.11.012

18. Hasunuma R, Ogawa T, Kawanishi Y (1982) Fluorometric determination of selenium in nanogram amounts in biological materials using 2,3-diaminonaphthalene. Anal Biochem 126(2):242-245

19. Peirson SN, Butler JN, Foster RG (2003) Experimental validation of novel and conventional approaches to quantitative real-time PCR data analysis. Nucleic Acids Res 31(14):e73 
20. Pfaffl MW (2001) A new mathematical model for relative quantification in real-time RT-PCR. Nucleic Acids Res 29(9):e45

21. Ren B, Zhu HQ, Luo ZF, Zhou Q, Wang Y, Wang YZ (2001) Preliminary research on myosin light chain kinase in rabbit liver. World J Gastroenterol : WJG 7(6):868-871

22. Rederstorff M, Krol A, Lescure A (2006) Understanding the importance of selenium and selenoproteins in muscle function. Cell Mol Life Sci 63(1):52-59. doi:10.1007/s00018-005-5313y

23. Burk RF, Hill KE, Motley AK (2001) Plasma selenium in specific and non-specific forms. Biofactors 14(1-4):107-114

24. Moustafa ME, Antar HA (2012) A bioinformatics approach to characterize mammalian selenoprotein T. Biochem Genet 50(910):736-747. doi:10.1007/s10528-012-9516-2

25. Anouar Y, Ghzili H, Grumolato L, Montero-Hadjadje M, Lesage J, Galas L, Ait-Ali D, Elkahloun AG, Vieau D, Vaudry H (2006) Selenoprotein $\mathrm{T}$ is a new PACAP- and cAMP-responsive gene involved in the regulation of calcium homeostasis during neuroendocrine cell differentiation. Front Neuroendocrinol 27(1):82-83. doi:10.1016/j.yfrne.2006.03.180

26. Wang R, Sun B, Zhang Z, Li S, Xu S (2011) Dietary selenium influences pancreatic tissue levels of selenoprotein $\mathrm{W}$ in chickens. J Inorg Biochem 105(9):1156-1160. doi:10.1016/j.jinorgbio.2011.05.022

27. Gao XJ, Xing HJ, Li S, Li JL, Ying T, Xu SW (2012) Selenium regulates gene expression of selenoprotein $\mathrm{W}$ in chicken gastrointestinal tract. Biol Trace Elem Res 145(2):181-188. doi:10.1007/s12011-011-9175-X

28. Zheng Y, Zhong L, Shen X (2005) Effect of selenium-supplement on the calcium signaling in human endothelial cells. J Cell Physiol 205(1):97-106. doi:10.1002/jcp.20378

29. Cheung WY (1980) Calmodulin plays a pivotal role in cellular regulation. Science 207(4426):19-27

30. Johnson JD, Snyder C, Walsh M, Flynn M (1996) Effects of myosin light chain kinase and peptides on $\mathrm{Ca}^{2+}$ exchange with the $\mathrm{N}$ - and $\mathrm{C}$-terminal $\mathrm{Ca}^{2+}$ binding sites of calmodulin. J Biol Chem 271(2):761-767

31. Wray S (1993) Uterine contraction and physiological mechanisms of modulation. Am J Physiol 264(1 Pt 1):C1-C18

32. Shojo H, Kaneko Y (2001) Oxytocin-induced phosphorylation of myosin light chain is mediated by extracellular calcium influx in pregnant rat myometrium. J Mol Recognit 14(6):401-405. doi:10.1002/jmr.551

33. Somlyo AP, Wu X, Walker LA, Somlyo AV (1999) Pharmacomechanical coupling: the role of calcium, G-proteins, kinases and phosphatases. Rev Physiol Biochem Pharmacol 134:201-234

34. Ikebe M, Stepinska M, Kemp BE, Means AR, Hartshorne DJ (1987) Proteolysis of smooth muscle myosin light chain kinase. Formation of inactive and calmodulin-independent fragments. J Biol Chem 262(28):13828-13834

35. Pawlowski J, Morgan KG (1992) Mechanisms of intrinsic tone in ferret vascular smooth muscle. J Physiol 448:121-132 